\title{
The IGF system in the neonatal ovine uterus
}

\author{
Kanako Hayashi ${ }^{1}$, Karen D Carpenter ${ }^{1}$, Thomas H Welsh Jr ${ }^{1}$, Robert C Burghardt $^{2}$, Leon J Spicer ${ }^{3}$ \\ and Thomas E Spencer ${ }^{1}$ \\ ${ }^{1}$ Center for Animal Biotechnology and Genomics and Department of Animal Science, Texas A\&M University, \\ College Station, Texas 77843, USA, ${ }^{2}$ Image Analysis Laboratory and Department of Veterinary Anatomy and Public \\ Health, Texas A\&M University, College Station, Texas 77843, USA and ${ }^{3}$ Department of Animal Science, Oklahoma \\ State University, Stillwater, Oklahoma 74078, USA
}

Correspondence should be addressed to T E Spencer; Email: tspencer@tamu.edu

\begin{abstract}
Postnatal development of the ovine uterus primarily involves uterine gland morphogenesis or adenogenesis. Adenogenesis involves the budding differentiation of the glandular epithelium (GE) from the luminal epithelium (LE) and then GE proliferation and coiling/branching morphogenetic development within the stroma between birth (postnatal day or PND 0) and PND 56. Insulin-like growth factor (IGF)-I and IGF-II mRNAs were previously found to be expressed only in the endometrial stroma, whereas the IGF receptor (IGF-1R) mRNA was most abundant in epithelia and in stroma, suggesting that an intrinsic IGF system regulates postnatal development of the uterus. Given that the biological activities of IGFs are modulated by a family of six IGF binding proteins (IGFBPs) and specific proteases, the objective was to determine the effects of age and estrogen disruption on expression of IGFs, IGFBPs and pregnancy-associated plasma protein A (PAPP-A or IGFBP-4 protease) in the ovine uterus. In Study One, circulating levels of IGF-I and IGF-II in the serum of neonatal ewes did not change between PND 0 and PND 56. Levels of immunoreactive IGF-I, IGF-II and IGF-1R protein were most abundant on the apical surface of the endometrial LE and GE. RT-PCR analyses detected expression of IGFBPs $(3,4,5$ and 6$)$ as well as PAPP-A mRNAs in the uterus, but not IGFBP-1 and IGFBP-2 mRNAs. IGFBP-3 and IGFBP-4 mRNAs were expressed specifically in the endometrial stroma and myometrium and increased after birth. PAPP-A mRNA was expressed specifically in the endometrial stroma and increased after birth. In Study Two, ewes were treated from birth with estradiol-17 $\beta$ valerate (EV), which reduces uterine growth and inhibits endometrial adenogenesis. On PNDs 14 and 56, IGFBP-3 mRNA was decreased in the uterus of EV-treated ewes, but IGF-1R and IGFBP-4 mRNAs were not affected. PAPP-A mRNA was increased by EV treatment on PND 14, but decreased on PND 56. These results support the hypothesis that an intrinsic IGF system in the uterus regulates epithelial-stromal interactions important for postnatal uterine growth and endometrial gland morphogenesis in the sheep.

Reproduction (2005) 129 337-347
\end{abstract}

\section{Introduction}

Postnatal development of the ovine uterus involves the emergence, proliferation and differentiation of endometrial glands, specification of intercaruncular stroma, development of endometrial folds and, to a lesser extent, growth of endometrial caruncular areas and the myometrium (Taylor et al. 2000, Gray et al. 2001a). Uterine gland development or adenogenesis is initiated between postnatal days (PNDs) 1 and 7 when shallow epithelial invaginations appear along the luminal epithelium (LE) in presumptive intercaruncular areas. Between PNDs 7 and 14 , the nascent glandular epithelia (GE) bud and invaginate into the stroma and then proliferate to form tubules or ducts that begin to coil and branch at the tips by PND 21. After PND 14, endometrial adenogenesis primarily involves coiling and slight branching morphogenetic growth of tubular endometrial glands from the upper stroma (e.g. stratum compactum) underneath the LE into the lower stroma (e.g. stratum spongiosum) adjacent to the inner circular layer of the myometrium. By PND 56, uterine morphogenesis is essentially complete, as the aglandular caruncular and glandular intercaruncular endometrial areas appear histoarchitecturally similar to that of the adult uterus (Taylor et al. 2000). The success of uterine development in the neonate directly impacts on the embryotrophic capacity of the adult uterus. Inappropriate exposure to progestins from birth to PND 56 permanently ablates endometrial gland development and results in a uterine gland knockout (UGKO) phenotype in the adult (Gray et al. 2001b). Adult UGKO ewes are infertile and exhibit a defect in peri-implantation conceptus survival 
and growth (Gray et al. 2001a, 2002). Therefore, it is important to understand the hormonal, cellular and molecular mechanisms governing postnatal uterine development (Bartol et al. 1999).

Insulin-like growth factors (IGF-I and IGF-II) function as endocrine and paracrine/autocrine hormones that stimulate proliferation and differentiation of many diverse cell types (Jones \& Clemmons 1995, Baxter 2000). Established components of the IGF system include IGF-I and IGF-II, type I and type II IGF receptors (IGF-1R and IGF-2R), six high affinity IGF binding proteins (IGFBP-1 to -6), and IGFBP proteases (Clemmons 1997, Hwa et al. 1999). In the neonatal ovine uterus, IGF-I and IGF-II mRNAs are expressed only in the endometrial stroma, whereas IGF$1 \mathrm{R}$ mRNA is expressed in all uterine cell types with the highest levels in the GE (Taylor et al. 2001). IGF-2R was not detected in the neonatal ovine uterus (Taylor et al. 2001). Interestingly, IGF-I and IGF-II mRNAs were most abundant in the stroma surrounding the developing glands in the intercaruncular areas of the endometrium (Taylor et al. 2001). Recently, estrogen disruption of uterine growth and endometrial adenogenesis was correlated with alterations in normal patterns of IGF-I, IGF-II and IGF-1R expression in the neonatal ewe (Carpenter et al. 2003a, Hayashi et al. 2004), supporting the idea that this intrinsic growth factor system regulates uterine development after birth. The IGF system is also implicated in postnatal rodent uterine development (Adesanya et al. 1999, Gu et al. 1999), and adult IGF-I null female mice have severe reductions in uterine weight and size (Baker et al. 1996). In mice, locally produced IGF-I can maintain normal growth and development in the absence of circulating IGF-I (Yakar et al. 1999). However, estrogen-induced uterine growth appears to require systemic IGF-I in mice (Sato et al. 2002). Collectively, available studies support the hypothesis that IGFs of local stromal origin are important mitogens that act in a classical epithelial-stromal manner on epithelial IGF-1R to regulate uterine growth and endometrial adenogenesis in the neonatal ewe. The systemic levels of IGFs in the neonatal ewe have not been reported in detail.

Six distinct yet structurally homologous IGF binding proteins, designated IGFBP-1 through IGFBP-6, function as regulators of the biological activities of IGF-I and IGF-II (Jones \& Clemmons 1995, Firth \& Baxter 2002). IGFBPs can either inhibit or enhance IGF activity and can also act independently of the IGFs. One IGFBP-4 protease is pregnancy-associated plasma protein A (PAPP-A) (Jones \& Clemmons 1995), which is a metalloproteinase in the metzincin superfamily that includes astacins, serralysins, adamalysins, and matrix metalloproteinases (MMPs) (Overgaard et al. 2000). Although IGFBP mRNA distribution has been reported in the adult ovine uterus during gestation (Wathes et al. 1998b, Nayak \& Giudice 2003), the IGFBP system has not been investigated in the developing neonatal ovine uterus. Our working hypothesis is that an intrinsic IGF system regulates postnatal uterine development and, in particular, endometrial adenogenesis in the neonatal ewe. Therefore, one objective of the present studies was to determine the effects of postnatal age on (1) systemic levels of IGF-I and IGF-II, (2) expression of IGF-I, IGF-II and IGF-1R protein in the uterus, and (3) expression of IGFBPs and PAPP-A in the uterus. The second objective was to determine the effects of estrogeninduced developmental disruption on expression of IGFBPs and PAPP-A in the neonatal ovine uterus.

\section{Materials and methods}

\section{Experimental design and tissue collection}

All experimental and surgical procedures were approved by the University Laboratory Animal Care and Use Committee of Texas A\&M University.

\section{Study One}

Crossbred Suffolk ewes were mated to Suffolk rams between November and December 2002. Ewes included in the following experiment were born between February and March 2003. All lambs were suckling their dams throughout the experiment. Crossbred, spring-born Suffolk ewes $(n=45)$ were assigned randomly at birth (PND 0$)$ to be hysterectomized on PND $0(n=6), 7$ $(n=4), 14(n=5), 21 \quad(n=5), 28(n=5), 35(n=5)$, $42(n=5), 49(n=5)$, or $56(n=5)$. Before surgery, blood samples were collected by jugular venipuncture, and serum was obtained by centrifugation after coagulation. At hysterectomy, the entire reproductive tract was excised, and the uterus was trimmed free of the broad ligament, oviduct, and cervix. Each uterine horn and ovary was fixed in $4 \%(\mathrm{w} / \mathrm{v})$ paraformaldehyde in PBS $(\mathrm{pH} 7.2)$. After $24 \mathrm{~h}$, fixed tissues were changed to $70 \%$ ethanol and then embedded in Paraplast Plus (Oxford Labware, St Louis, MO, USA). Several sections from the middle of each uterine horn were snap-frozen in TissueTek OCT compound (SAKURA Finetek USA Inc., Torrance, CA, USA). The remainder of the uterus was frozen in liquid nitrogen and stored at $-80^{\circ} \mathrm{C}$.

\section{Study Two}

Crossbred Suffolk ewes were mated to Suffolk rams between July and October 2003. Ewes included in the following experiment were born between October 2003 and January 2004, and lambs were suckling their dams throughout the experiment. As described previously (Carpenter et al. 2003a), ewes $(n=14)$ were assigned randomly at birth (PND 0) to receive daily i.m. injections from PND 0 to PND 55 of: (1) corn oil vehicle as a control (CX) or (2) estradiol-17 $\beta$ valerate (EV; Sigma) in corn oil at a dose of $50 \mu \mathrm{g}$ per $\mathrm{kg}$ body weight. Ewes were weighed and the EV dose adjusted every 7 days. On PND 14, the right ovarian pedicle was ligated with a suture, and the ovary and oviduct were removed. The right uter- 
ine horn was ligated with a suture above the intercornual ligament, and the anterior portion of the right uterine horn above the ligature was removed, fixed in $4 \%(\mathrm{w} / \mathrm{v})$ paraformaldehyde in PBS ( $\mathrm{pH}$ 7.2), and processed for histology. On PND 56, all ewes were killed and necropsied. The entire left uterine horn was dissected from the remaining portion of the right uterine horn, fixed in $4 \%(\mathrm{w} / \mathrm{v})$ paraformaldehyde in PBS ( $\mathrm{pH} 7.2$ ), and processed for histology. The remainder of the uterus was frozen in liquid nitrogen and stored at $-80^{\circ} \mathrm{C}$.

\section{IGF-I radioimmunoassay (RIA)}

Blood samples for serum were allowed to clot for $1 \mathrm{~h}$ at room temperature. Serum was then collected by centrifugation $\left(3000 \times g\right.$ for $30 \mathrm{~min}$ at $\left.4{ }^{\circ} \mathrm{C}\right)$, removed, and stored at $-20^{\circ} \mathrm{C}$. Serum concentrations of IGF-I were determined by a double-antibody RIA procedure (Bilby et al. 1999) with all the samples processed in a single assay. The primary antibody was obtained from Dr A F Parlow, National Hormone and Pituitary Program (UCLA Medical Center, Torrance, CA, USA). The standard curve, ranging from $2 \mathrm{pg}$ to $1000 \mathrm{pg} /$ tube, was constructed using recombinant IGF-I from Peninsula Labs (Belmont, CA, USA). lodinated IGF-I (Cat\# H-5406) tracer was from Peninsula Labs. Normal rabbit serum and goat anti-rabbit antibody were from Antibodies, Inc. (Davis, CA, USA). Briefly, serum samples $(10 \mu \mathrm{l})$ were incubated with $500 \mu \mathrm{l}$ assay buffer $(0.02 \%$ protamine sulfate, $30 \mathrm{mM}$ sodium phosphate, $0.05 \%$ Tween $20,0.02 \%$ sodium azide, and $0.01 \mathrm{M}$ EDTA, pH 7.5) and $400 \mu \mathrm{l} 1 \mathrm{M}$ glycine (pH 3.2) for $48 \mathrm{~h}$ at $37^{\circ} \mathrm{C}$. After incubation, the acidified samples were neutralized with $90 \mu \mathrm{l} 0.05 \mathrm{M} \mathrm{NaOH}$. Duplicate $50 \mu \mathrm{l}$ aliquots of the acidified samples were assayed. The RIA tubes (polypropylene, $12 \times 75 \mathrm{~mm}$ ) were incubated at $4{ }^{\circ} \mathrm{C}$ in the presence of primary antibody for a 24-h period, after which iodinated IGF-I (20000c.p.m./100 $\mu \mathrm{l}$ ) was added for an additional incubation period of $18 \mathrm{~h}$ at $4{ }^{\circ} \mathrm{C}$. The assay was terminated by addition of $50 \mu \mathrm{l}$ normal rabbit serum (1:100 dilution), $50 \mu$ l goat anti-rabbit antibody $(1: 60)$ and $300 \mu$ l of a polyethylene glycol solution (12.5\% w/v; 8000 Da molecular mass; Sigma). The RIA tubes were incubated for $30 \mathrm{~min}$ before centrifugation at $4{ }^{\circ} \mathrm{C}$. The supernatant was discarded and radioactivity associated with the pellet (bound fraction) was determined by counting for $2 \mathrm{~min}$ on a gamma counter. Acidified serum samples representing high, medium and low concentrations of IGF-I were assayed to represent internal quality control pools. The mean intra-assay coefficient of variation was $4.6 \%$, and the assay sensitivity was $3.6 \mathrm{pg} / \mathrm{ml}$.

\section{IGF-II RIA}

Concentrations of IGF-II in serum were determined by double antibody RIA in one assay as previously described (Spicer et al. 1995) with the following modifications. The tracer and standard were recombinant human IGF-II, and the extraction was performed using acid ethanol $(16 \mathrm{~h}$ at $4{ }^{\circ} \mathrm{C}$ ) as previously described (Echternkamp et al. 1990). The assay sensitivity, defined as $95 \%$ of total binding, was $14 \mathrm{ng} / \mathrm{ml}$ and the intra-assay $\mathrm{CV}$ was $2.8 \%$.

\section{RT-PCR analyses}

Partial cDNAs for IGF-1R, IGFBP-1 through IGFBP-6, and PAPP-A mRNAs were generated by RT-PCR using total RNA, isolated from the neonatal ovary, neonatal uterus or endometrium from gestational day (GD) 16, as described previously (Taylor et al. 2000, 2001, Hayashi et al. 2003). Primer and annealing temperatures used for PCR are summarized in Table 1 . The amplified PCR products were subcloned into the pCRII cloning vector using a T/A Cloning Kit (Invitrogen Life Technologies, Carlsbad, CA, USA) and sequenced in both directions using an ABI PRISM Dye Terminator Cycle Sequencing Kit and ABI PRISM automated DNA sequencer (Perkin-Elmer Applied Biosystems, Foster City, CA, USA) to confirm identity.

Table 1 Summary of PCR primer sequences and expected cDNA sizes.

\begin{tabular}{|c|c|c|c|c|}
\hline Primer & Sequences of forward and reverse primers $\left(5^{\prime}-3^{\prime}\right)$ & GenBank (species) & Annealing temperature $\left({ }^{\circ} \mathrm{C}\right)$ & cDNA size (bp) \\
\hline IGF-IR & $\begin{array}{l}\text { GAGATTGCAGATGGCATGG } \\
\text { GCTGATGATCTCCAGGAACG }\end{array}$ & $\begin{array}{l}\text { X54980 } \\
\text { (bovine) }\end{array}$ & 56 & 441 \\
\hline IGFBP-1 & $\begin{array}{l}\text { GATGACCGAGTCCAGTGAGG } \\
\text { CCATTCTTGTTGCAGTTTGG }\end{array}$ & $\begin{array}{l}\text { AF327650 } \\
\text { (ovine) }\end{array}$ & 54 & 210 \\
\hline IGFBP-2 & $\begin{array}{l}\text { AGCAGGTTGCAGACAATGG } \\
\text { ACAGTTGGGGATGTGTAGGG }\end{array}$ & $\begin{array}{l}\text { S44612 } \\
\text { (ovine) }\end{array}$ & 54 & 353 \\
\hline IGFBP-3 & $\begin{array}{l}\text { CAGAACTTCTCCTCCGAGTCC } \\
\text { CCACACACCAGCAGAAACC }\end{array}$ & $\begin{array}{l}\text { AF327651 } \\
\text { (ovine) }\end{array}$ & 54 & 205 \\
\hline IGFBP-4 & $\begin{array}{l}\text { CTTGGCCAAAATTCGAGACC } \\
\text { AAGCTTCACTCCCGTCTTCC }\end{array}$ & $\begin{array}{l}\text { S77394 } \\
\text { (ovine) }\end{array}$ & 54 & 286 \\
\hline IGFBP-5 & $\begin{array}{l}\text { GCGGCGTCTACACTGAGC } \\
\text { GAAGATCTTGGGCGAGTAGG }\end{array}$ & $\begin{array}{l}\text { S52657 } \\
\text { (bovine) }\end{array}$ & 54 & 212 \\
\hline IGFBP-6 & $\begin{array}{l}\text { AAGGAGAGTAAGCCCCAAGC } \\
\text { GGCACGTAGAGTGTATGAGACC }\end{array}$ & $\begin{array}{l}\text { AF327653 } \\
\text { (ovine) }\end{array}$ & 54 & 212 \\
\hline PAPP-A & $\begin{array}{l}\text { ACACATGTGGCTTCAACAGC } \\
\text { AGACAAAGGTCACCCAGACG }\end{array}$ & $\begin{array}{l}\text { AF421140 } \\
\text { (ovine) }\end{array}$ & 54 & 552 \\
\hline
\end{tabular}




\section{In-situ hybridization}

Expression of mRNAs in uterine tissues was determined by in-situ hybridization using methods described previously (Spencer et al. 1999). Briefly, deparaffinized, rehydrated, and deproteinated cross-sections $(5 \mu \mathrm{m})$ of the uterus and ovary from each ewe were hybridized with radiolabeled sense or antisense cRNA probes generated from linearized plasmid templates using in vitro transcription with $\left[\alpha-{ }^{35}\right.$ S $]$ UTP. After hybridization, washing and ribonuclease A digestion, slides were dipped in NTB-2 liquid photographic emulsion (Kodak, Rochester, NY, USA), stored at $4{ }^{\circ} \mathrm{C}$ for 7 to 28 days, and developed in Kodak D-19 developer. Slides were then counterstained with Gill's modified hematoxylin (Stat Lab, Lewisville, TX, USA), dehydrated through a graded series of alcohol to xylene, and protected with a coverslip. Images of representative fields were recorded using a Nikon Eclipse 1000 photomicroscope (Nikon Instruments Inc., Lewisville, TX, USA) fitted with a Nikon DXM1200 digital camera.

\section{Immunofluorescence analyses}

Rabbit anti-human IGF-I (H-70), IGF-II (H-103) and IGF1R (H-78) antibodies were from Santa Cruz Biotechnology (Santa Cruz, CA, USA). Normal rabbit IgG was from Santa Cruz, and fluorescein-conjugated goat antibody against rabbit IgG was from Chemicon International (Temecula, CA, USA). Proteins were localized in frozen uterine crosssections $(8 \mu \mathrm{m})$ using methods previously described (Johnson et al. 1999). Briefly, tissues were fixed in $-20^{\circ} \mathrm{C}$ methanol, permeabilized with $0.3 \%$ Tween 20 in PBS, blocked in $10 \%$ normal goat serum, incubated overnight at $4{ }^{\circ} \mathrm{C}$ with 2 to $10 \mu \mathrm{g} / \mathrm{ml}$ primary antibody, and detected with fluorescein-conjugated secondary antibodies. Slides were then overlaid with a coverglass. Photomicrographs of representative fields of immunofluorescence were evaluated using a Zeiss Axioplan2 microscope interfaced with a AxioCam high resolution digital camera and AxioVision 3.1 software (AxioVision, Thornwool, NY, USA). Representative fluorescence images of cross-section for each antibody and for each ewe were recorded digitally.

As described previously (Taylor et al. 2001, Hayashi et al. 2003), relative hybridization signal intensity for staining intensity for immunoreactive protein expression was assessed visually in uterine sections from each ewe by two independent observers and scored as follows: absent i.e. no staining above $\lg G$ control $(-)$, weak $(+)$, moderate $(++)$, or strong $(+++)$. Intercaruncular endometrial tissues, including LE, stroma, GE, and myometrium were scored. The GE was separated into stratum compactum and stratum spongiosum.

\section{Statistical analyses}

All quantitative data were subjected to least-squares ANOVA using General Linear Models procedures of the Statistical Analysis System (Cary, NC, USA). Data are presented as least-square means with overall standard errors (S.E.).

\section{Results}

\section{Systemic levels of IGF-I and IGF-II}

Circulating levels of IGF-I and IGF-II in the serum of neonatal ewes did not change $(P>0.10)$ between birth and PND 56 (Fig. 1).

\section{Expression of IGF-I, IGF-II and IGF-1R protein in the neonatal uterus}

Immunofluorescence analyses were performed to localize immunoreactive IGF-I, IGF-II and IGF-1R protein in the neonatal uterus (Fig. 2). Results of immunofluorescence analyses were quantified and are summarized in Table 2. Low levels of immunoreactive IGF-I protein were observed on the apical surface of the endometrial LE and GE between birth and PND 56. Immunoreactive IGF-II protein was detected in all endometrial cell types; however, abundant IGF-II protein was detected on the apical surface of the endometrial LE and GE. Similarly, immunoreactive IGF-1R protein was detected predominantly on the apical surface of the endometrial LE and GE and at much lower abundance in the stroma and myometrium. The abundance of immunoreactive IGF-1R protein increased in the endometrial GE after PND 21.

\section{Expression of IGFBPs and PAPP-A in the neonatal uterus}

In order to determine which of the six IGFBP family members was expressed in the neonatal ovine uterus, RT-PCR analysis was performed using total RNA isolated from the neonatal uterus. Total RNA isolated from ovine endometrium from day 16 of gestation (GD 16) and a PND 42 ovary were used as positive controls (data not shown).

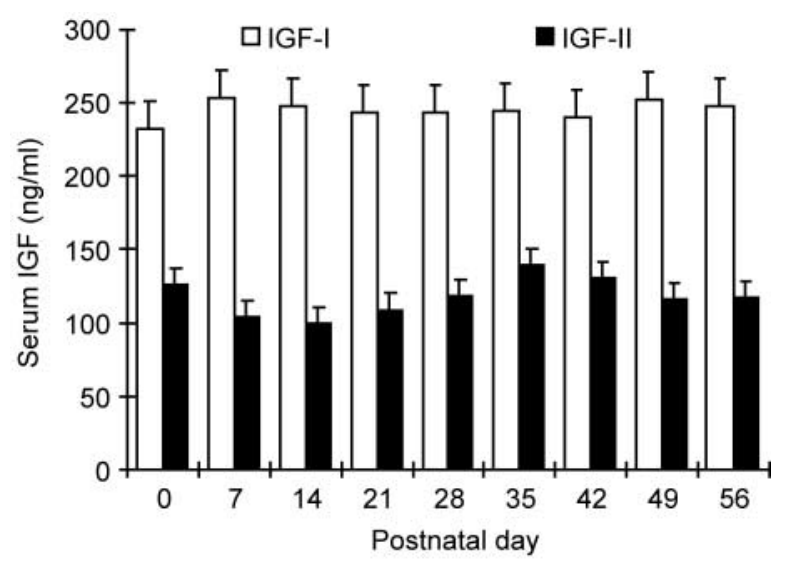

Figure 1 Systemic levels of IGF-I and IGF-II in the serum of neonatal ewes between postnatal day (PND) 0 and PND 56 ( $n=4-6$ ewes per day). Levels of both IGFs were not affected by postnatal age $(P>0.10)$. 


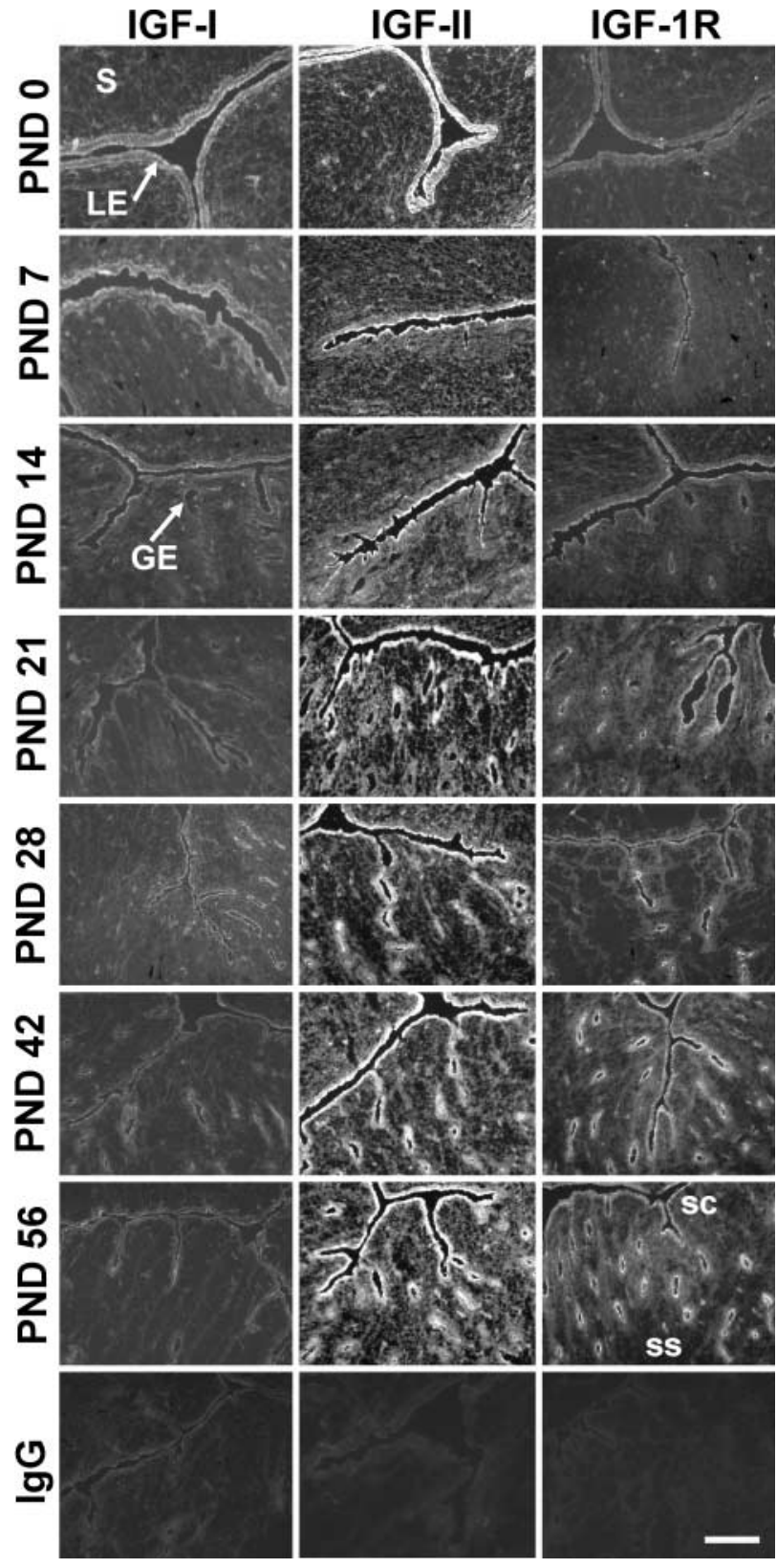

Figure 2 Distribution of immunoreactive IGF-I, IGF-II and IGF-1R in the neonatal ovine uterus on postnatal days (PND) 0, 7, 14, 21, 28, 42 and 56. GE, glandular epithelium; LE, luminal epithelium;

S, stroma; sc, stratum compactum; ss, stratum spongiosum. Scale bar, $100 \mu \mathrm{m}$.

IGFBP-1 mRNA was not detected in either the neonatal ovine uterus or ovary, but was detected in the endometrium from GD 16. IGFBP-2 mRNA was detected in GD 16 endometrium and PND 42 ovary, but not in the neonatal uterus. IGFBP-3, $-4,-5$ and -6 mRNAs were detected in the neonatal ovine uterus and ovary as well as GD 16 endometrium. PAPP-A mRNA was detected in the uterus on all PNDs (data not shown).

In-situ hybridization analyses were conducted to localize expression of IGFBP mRNAs in the neonatal ovine
Table 2 Distribution and relative abundance of immunoreactive IGF-I, IGF-II and IGF-1R protein in the neonatal uterus.

\begin{tabular}{|c|c|c|c|c|c|}
\hline \multirow[b]{2}{*}{ PND } & \multirow[b]{2}{*}{ LE } & \multicolumn{2}{|c|}{ GE } & \multirow[b]{2}{*}{ Stroma } & \multirow[b]{2}{*}{ Myometrium } \\
\hline & & Str. comp. & St. spons. & & \\
\hline \multicolumn{6}{|l|}{$I G F-I$} \\
\hline 0 & +++ & NP & NP & $+/-$ & $+/-$ \\
\hline 7 & +++ & ++ & NP & $+/-$ & $+/-$ \\
\hline 14 & ++ & + & NP & $+/-$ & $+1-$ \\
\hline 21 & + & + & + & - & $+/-$ \\
\hline 28 & $+/-$ & $+/-$ & $+1-$ & - & $+/-$ \\
\hline 42 & $+/-$ & $+/-$ & $+/-$ & - & $+/-$ \\
\hline $\begin{array}{l}56 \\
I G F-I I\end{array}$ & $+/-$ & $+1-$ & $+1-$ & - & $+1-$ \\
\hline 0 & +++ & NP & NP & + & ++ \\
\hline 7 & +++ & ++ & NP & + & ++ \\
\hline 14 & +++ & ++ & NP & + & ++ \\
\hline 21 & +++ & ++ & + & +/++ & ++ \\
\hline 28 & +++ & ++ & + & t/++ & ++ \\
\hline 42 & +++ & ++ & + & $+/++$ & ++ \\
\hline 56 & +++ & ++ & + & $+/++$ & ++ \\
\hline \multicolumn{6}{|c|}{$I G F-1 R$} \\
\hline 0 & + & NP & NP & $-1+$ & - \\
\hline 7 & + & + & NP & $-1+$ & - \\
\hline 14 & + & + & NP & $-/+$ & - \\
\hline 21 & ++ & ++ & + & + & - \\
\hline 28 & ++ & +++ & +++ & + & - \\
\hline 42 & ++ & +++ & +++ & + & - \\
\hline 56 & ++ & +++ & +++ & + & - \\
\hline
\end{tabular}

PND, postnatal day; LE, luminal epithelium; GE, glandular epithelium (shallow or stratum compactum and deep or stratum spongiosum); NP, not present.

-, no staining above IgG control; +, weak staining; ++, moderate staining; +++ , strong staining.

uterus (Fig. 3). Consistent with the results of RT-PCR analyses, expression of IGFBP-1 and IGFBP-2 mRNA was not detected in the neonatal ovine uterus (data not shown). IGFBP-3 and IGFBP-4 mRNAs were detected only in the endometrial stroma and myometrium. The overall abundance of both IGFBP-3 and IGFBP-4 mRNAs was low or undetectable in the endometrial stroma and myometrium on PND 0 and increased thereafter. Although IGFBP-5 and IGFBP- 6 mRNAs were detected in the neonatal ovine uterus by RT-PCR, the overall abundance was below the detectable limits of in-situ hybridization analysis (data not shown). PAPP-A mRNA was detected specifically in the stratum compactum stroma in both caruncular and intercaruncular endometrial areas, and increased between PND 0 and PND 56 (Fig. 4). PAPP-A mRNA was not observed in the endometrial LE or GE nor myometrium. Groups of pigmented melanocytes also produce a prominent signal in darkfield microscopy even though they do not express IGFBP or PAPP-A mRNAs.

\section{Expression of IGF-IR, IGFBPS and PAPP-A in the EV- treated neonatal uterus}

In Study Two, treatment of ewes from birth with EV affected uterine development and endometrial adenogenesis (Fig. 5). The endometrium from uteri of EV-treated ewes on both PND 14 and PND 56 did not contain any histologically 
a) IGFBP-3 mRNA

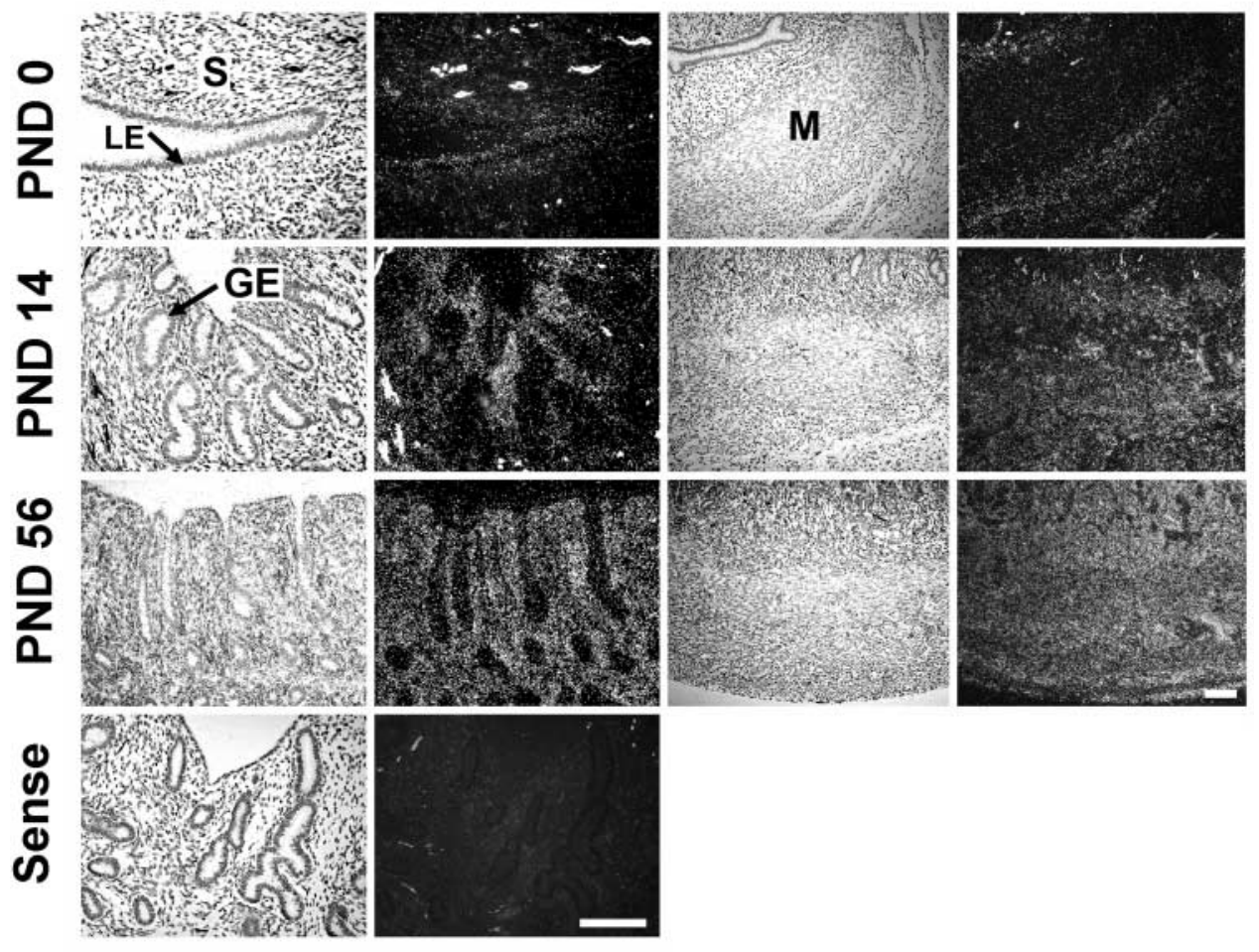

\section{b) IGFBP-4 mRNA}

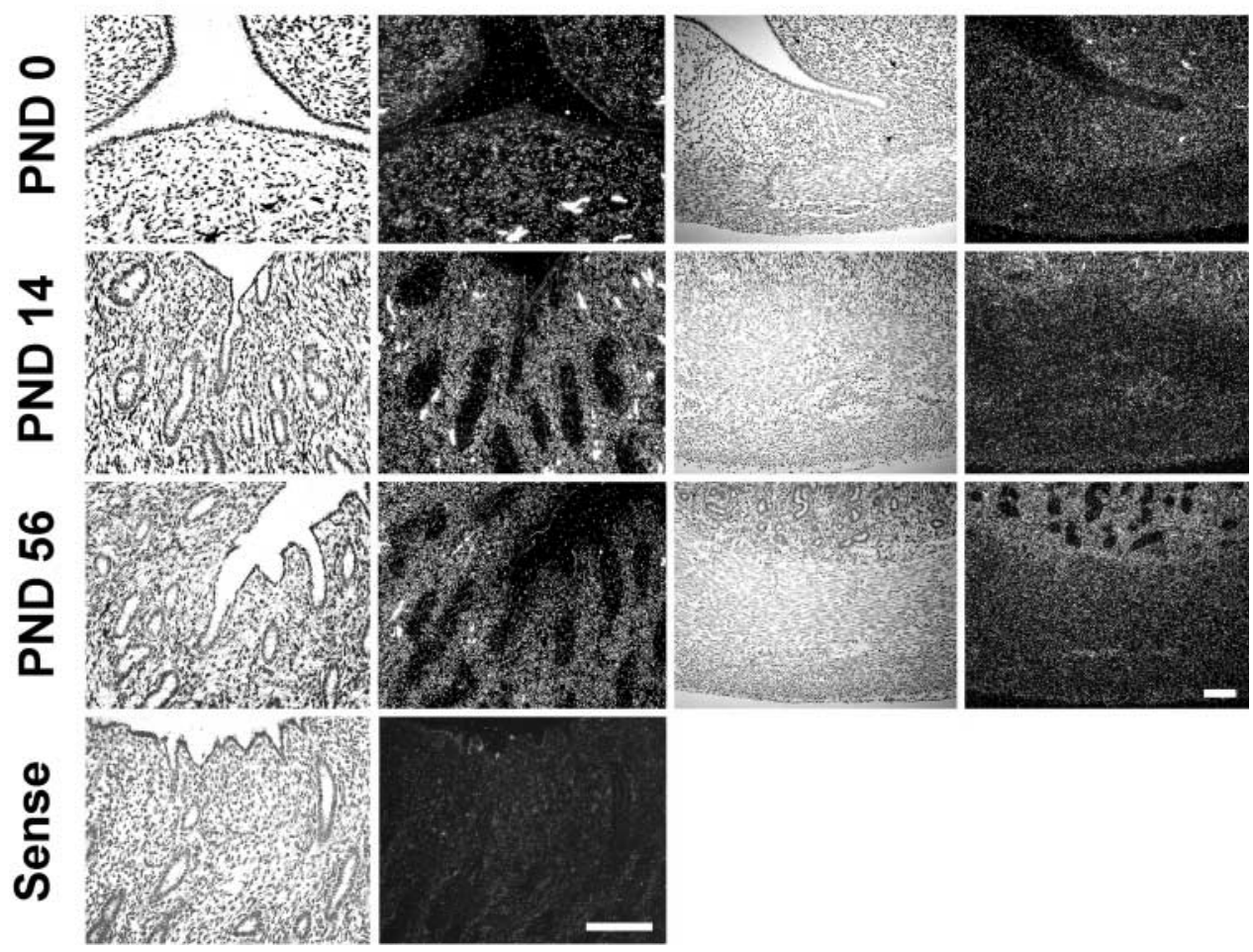

Figure 3 In-situ localization of (a) IGFBP-3 and (b) IGFBP-4 mRNA in the neonatal ovine uterus on postnatal days (PND) 0, 14 and 56. The photomicrographs are presented in brightfield (left) and darkfield (right) illumination. GE, glandular epithelium; LE, luminal epithelium; M, myometrium; S, stroma. Scale bar, $100 \mu \mathrm{m}$. 


\section{PAPP-A mRNA}

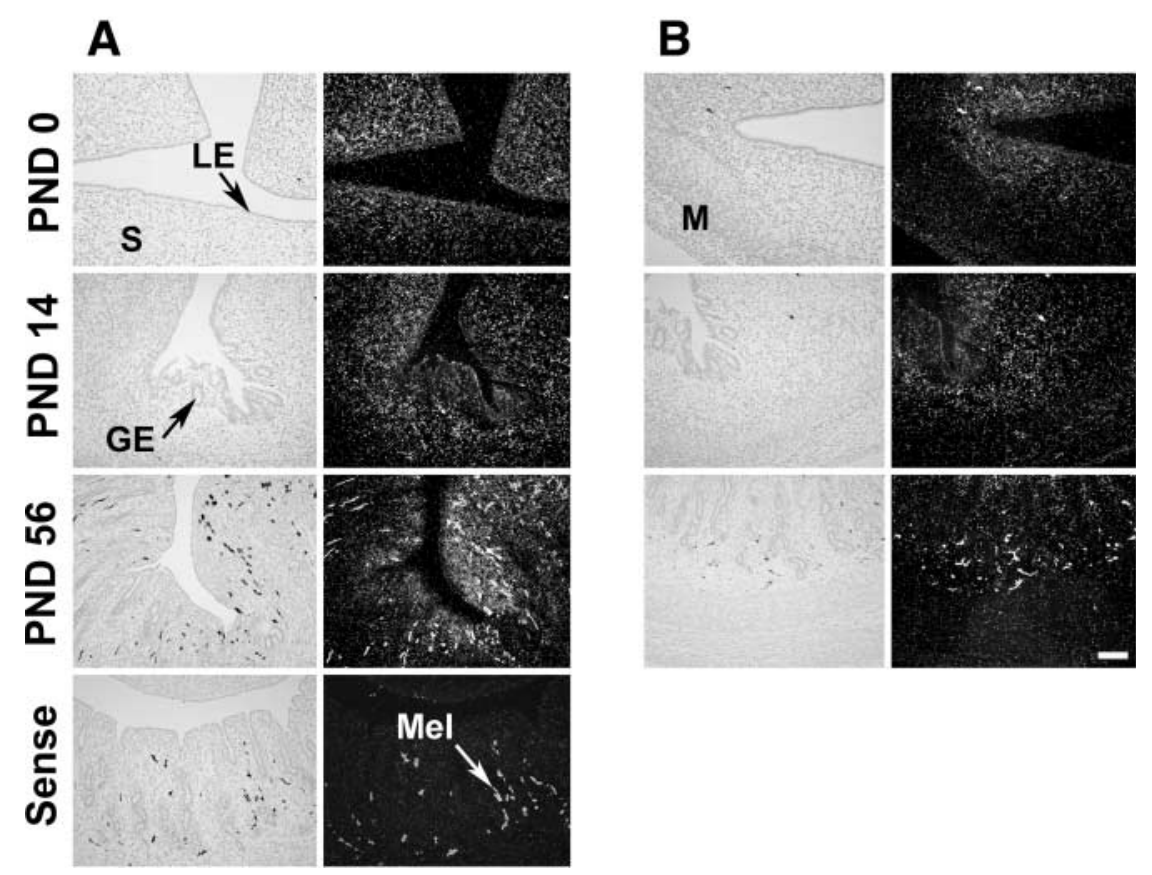

Figure 4 In-situ localization of PAPP-A mRNA in the neonatal ovine uterus. Left two columns (A) focus on endometrium, right (B) focus on myometrium. The photomicrographs are presented in brightfield (left) and darkfield (right) illumination. GE, glandular epithelium; LE, luminal epithelium; Mel, melanocyte; M, myometrium; S, stroma. Scale bar, $100 \mu \mathrm{m}$.

discernable endometrial glands. Expression of IGF-1R mRNA was observed abundantly in the endometrial LE and GE with lower levels in the stroma in CX ewes on PNDs 14 and 56 and was not affected by exposure to EV (Fig. 5a). IGFBP-3 mRNA was detected in the stroma and myometrium on PND 14, and expression was markedly increased on PND 56 in CX ewes (Fig. 5b). Treatment with EV decreased IGFBP-3 mRNA in the myometrium on PND 14 and predominantly in the stroma on PND 56 (Fig. 5b). In contrast, EV did not affect expression of IGFBP-4 mRNA in the stroma on PND 14 or PND 56 (Fig. 5c). On the other hand, PAPP-A mRNA was increased in the stroma of EVtreated ewes on PND 14, but was reduced on PND 56 as compared with CX ewes (Fig. 5d).

\section{Discussion}

In the present study, circulating levels of IGF-I and IGF-II were not different between birth and PND 56. The levels of circulating IGF-I and IGF-II observed in the present study were within the range of values previously reported for neonatal lambs (Mesiano et al. 1987, 1989). Plasma IGF-I increased in ram lambs between birth and PNDs 4 to 9 and was dependent on suckling (Greenwood et al. 2002). Furthermore, IGF-I and IGF-II increased between PNDs 0 and 20 in suckling ram and ewe lambs, and the increase between PNDs 1 and 16 was greater in ram lambs than in ewe lambs (Gatford et al. 1997). Overall, circulating IGF levels in ewes in the present study were not substantially different from previous reports. Therefore, systemic IGFs could play a regulatory role in postnatal uterine development. The importance of local and systemic IGFs in normal growth and development of tissues remains a subject of some debate. In mice, locally produced IGF-I can maintain normal growth and development in the absence of circulating IGF-I (Yakar et al. 1999), whereas estrogen-induced uterine growth appears to require systemic IGF-I (Sato et al. 2002). In the neonatal ewe, circulating levels of estradiol-17 $\beta$ are below detectable limits after birth to at least PND 56 (Carpenter et al. 2003a,c), suggesting that circulating IGF-I and IGF-II are not regulated by ovarian steroids in the neonatal ewe.

Previous studies found that IGF-I and IGF-II mRNAs were expressed in the endometrial stroma of the neonatal ovine uterus surrounding the developing glands (Taylor et al. 2001, Carpenter et al. 2003a). IGF-1R mRNA was expressed by all uterine cell types, but was particularly abundant in the endometrial epithelia. The same pattern of IGF-I, IGF-II and IGF-1R mRNA expression was observed in the adult ovine uterus (Stevenson et al. 1994). The present study is the first to localize the expression of immunoreactive IGF-I, IGF-II and IGF-1R protein in the ovine uterus. Immunoreactive IGF-I protein was detected at fairly low levels on the endometrial LE and, to some extent, GE. In contrast, immunoreactive IGF-II protein was localized in relative abundance on the apical surface of the endometrial LE and GE. The biological effects of IGF-I and IGF-II are mediated by the IGF-1R in most tissue and 


\section{a) IGF-IR mRNA}

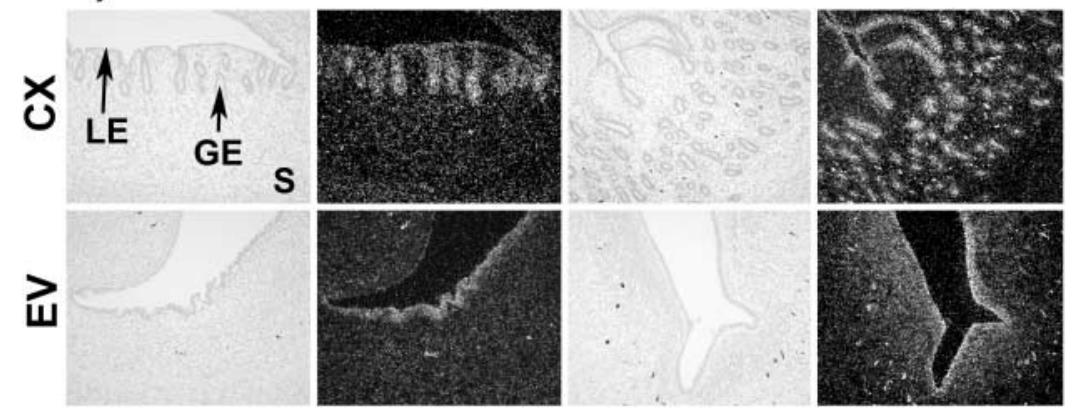

b) IGFBP-3 mRNA

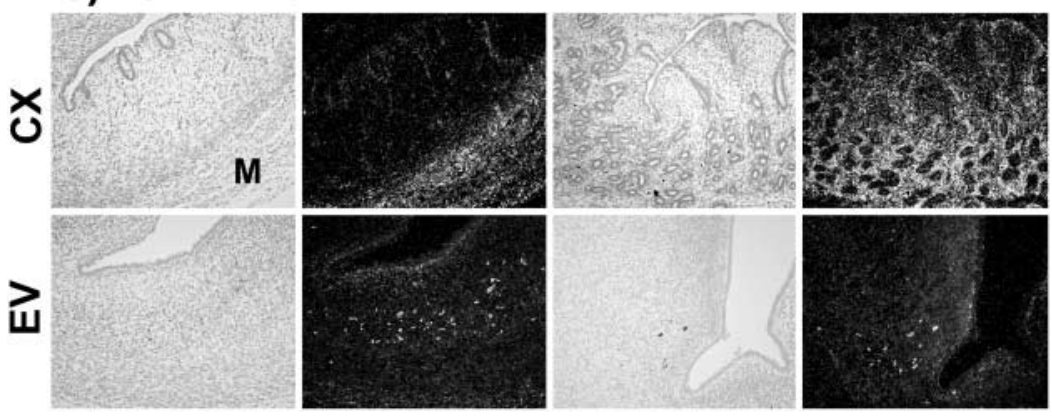

c) IGFBP-4 mRNA

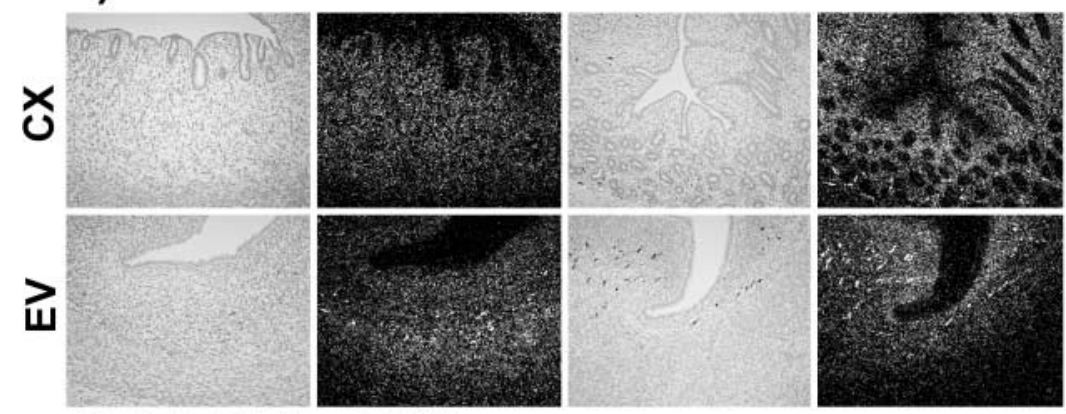

d) PAPP-A mRNA

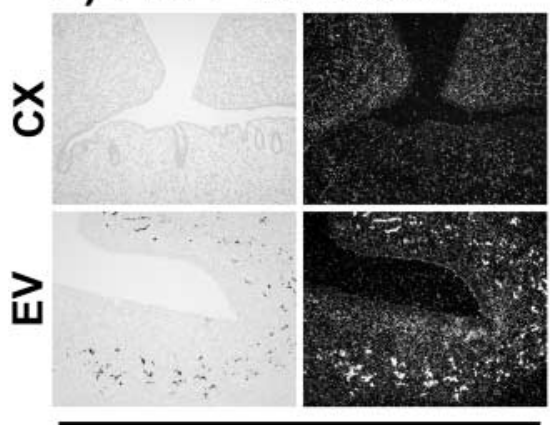

PND 14

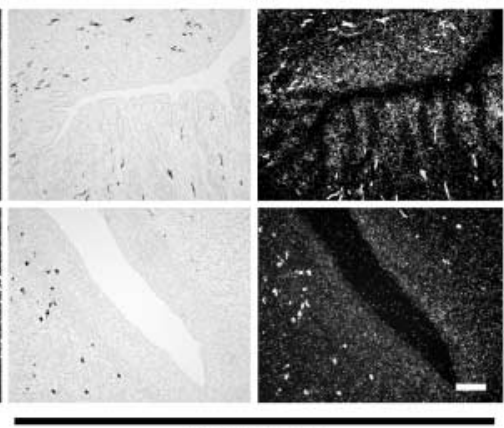

PND 56

Figure 5 Expression of (a) IGF-1R, (b) IGFBP-3, (c) IGFBP-4 and (d) PAPP-A mRNAs in uteri from control (CX) and estradiol valerate (EV)-treated ewes on PNDs 14 and 56. The photomicrographs are presented in brightfield (left) and darkfield (right) illumination. GE, glandular epithelium; LE, luminal epithelium; M, myometrium; S, stroma. Scale bar, $100 \mu \mathrm{m}$.

cell systems (Jones \& Clemmons 1995). Although immunoreactive IGF-1R protein was observed in all uterine cell types, the most abundant expression was detected on the apical surfaces of endometrial LE and GE during postnatal development. Collectively, available results strongly support the idea that local IGF-I and IGF-II of stromal origin act on IGF-1R in the epithelium and stroma to regulate uterine growth and endometrial adenogenesis in the neonatal ewe (Taylor et al. 2001, Carpenter et al. 2003a, Hayashi et al. 2004). Although IGF-II plays a 
fundamental role in embryonic and fetal development, its role during the postnatal period is generally thought to be less important since it is substituted by IGF-I (DeChiara et al. 1990). Interestingly, IGF-II gene expression was not observed in the neonatal mouse uterus (Gu et al. 1999), but was detected in the neonatal ovine uterus in the present study, and in the adult ovine and human uterus (Wathes et al. 1998a, Nayak \& Giudice 2003). Given the lack of IGF-II in the neonatal mouse uterus, the precise role of IGF-II in uterine development and function remains to be determined using other models such as domestic ruminants.

The activities of both IGF-I and IGF-II are modulated by their association with six IGFBPs (Jones \& Clemmons 1995). By binding IGF-I and IGF-II, IGFBPs have growthinhibitory effects by restricting the availability of these ligands for binding to IGF-1R (Rechler \& Brown 1992, Jones \& Clemmons 1995). On the contrary, the IGFBPs also regulate IGF bioavailability by maintaining a circulating reservoir of IGFs and prolonging their half-life (Ferry et al. 1999). At the tissue level, IGFBPs interact with either extracellular matrix constituents (IGFBP-2 and IGFBP-5) (Arai et al. 1996) or directly with cell membranes (IGFBP1 and IGFBP-3) (Delbe et al. 1991). In the present study, RT-PCR analyses of the neonatal ovine uterus detected expression of only IGFBP-3, $-4,-5$ and -6 mRNAs. In-situ hybridization localized expression of IGFBP-3 and IGFBP4 mRNAs only in the endometrial stroma and myometrium of the neonatal ovine uterus, whereas IGFBP-5 and IGFBP-6 mRNAs were below detectable limits of the insitu hybridization procedure. Overall, expression of IGFBP-3 and IGFBP-4 mRNAs increased after birth and was highest in the stroma during the period of endometrial gland morphogenesis. Potentiation and inhibition of IGF actions by IGFBP-3 has been demonstrated in many cell culture systems (Firth \& Baxter 2002). Interestingly, IGFBP-3 has IGF-1R-independent actions to inhibit cell growth (Valentinis et al. 1995). Moreover, IGFBP-3 interacts with and modifies the biological activities of a number of other growth factors, including transforming growth factor beta and retinoids (Firth \& Baxter 2002).

The action of IGFBP-4 appears to be purely inhibitory with respect to both IGF-I and IGF-II (Jones \& Clemmons 1995). IGFBP-4 availability in the microenvironment is determined not only by specific gene expression, but also through limited proteolysis by specific proteases such as PAPP-A (Fowlkes 1997). Enzymatic cleavage of IGFBP-4 by PAPP-A markedly reduces its binding of IGFs and potentiates the effectiveness of exogenous IGF-I in stimulating receptor-mediated growth responses in cultured cells (Qin et al. 1999). In the present study, PAPP-A mRNA was expressed specifically in the compact stroma of the endometrium in the neonatal ovine uterus. Expression of PAPP-A increased from birth to PND 56 in association with uterine growth and endometrial gland morphogenesis. Thus, bioavailability of local IGF-I and IGF-II in the uterine microenvironment may be regulated through controlled IGFBP-4 proteolysis by PAPP-A. Similarly, PAPP-A, IGFBP-4, and IGF appear to function together in the ovary and uterus in other species (Conover et al. 2001, Giudice et al. 2002, Mazerbourg et al. 2004).

In the present study, expression of IGFBP-1 and IGFBP2 was not detected in the neonatal uterus by RT-PCR. Furthermore, expression of IGFBP-5 and IGFBP- 6 mRNA was only detectable using very high cycles of amplification (30-35 cycles) in the RT-PCR analyses (K Hayashi and T E Spencer, unpublished results), and expression of these IGFBPs was below detectable limits of the in-situ hybridization analysis. In adult ewes, these IGFBPs are expressed in the uterus during the estrous cycle and pregnancy (Reynolds et al. 1997, Osgerby et al. 1999, Gadd et al. 2000). IGFBP-1 mRNA is expressed by the LE during early pregnancy and then declines to undetectable levels during later stages of gestation (Osgerby et al. 1999). IGFBP$2 \mathrm{mRNA}$ is undetectable in the uterus during the estrous cycle, but is abundant in the dense stroma of the placentomal capsule after GD 29, which also expresses IGFBP-4 (Reynolds et al. 1997). In cyclic ewes, IGFBP-5 mRNA is present in the caruncular endometrium and in the intercaruncular endometrial LE (Gadd et al. 2000). During pregnancy, IGFBP-5 is also present in the endometrial LE and GE as well as in caruncular stroma surrounding the chorionic villi. Available studies indicate that the expression of the genes encoding IGFBP-1 through IGFBP6 are regulated by steroid hormones during the estrous cycle and potential conceptus factors during pregnancy (Wathes et al. 1998a, Nayak \& Giudice 2003). In the present study, IGFBP-3 and IGFBP-4 mRNAs were observed only in the endometrial stroma and not in the endometrial LE as in the adult ovine uterus. Therefore, factors from the ovary, e.g. estrogen and progesterone, and from the conceptus appear to act on the ovine endometrium to regulate IGFBP gene expression after puberty in a tissue- and cell type-specific manner.

Available results strongly support the hypothesis that the intrinsic IGF system (IGF-I, IGF-II, IGFBP-3, IGFBP-4, and PAPP-A) is an important regulator of endometrial gland morphogenesis and uterine growth in the developing neonatal ewe. In Study Two, exposure of neonatal ewes to EV from birth did not affect epithelial IGF-1R or stromal IGFBP-4 mRNA, but did decrease IGFBP-3 mRNA in the stroma. In the EV-treated ewes, PAPP-A mRNA in the stroma was increased initially on PND 14, but was decreased by PND 56. The negative effects of EV exposure to decrease IGFBP-3 and increase PAPP-A would be predicted to modify biological activities of IGFs in the endometrium. However, stromal IGF-I and IGF-II expression is substantially decreased in the endometrium of EV-treated ewes (Carpenter et al. 2003a). Similarly, disruption of uterine growth and endometrial adenogenesis by inappropriate exposure of the neonatal ewe to estradiol- $17 \beta$ benzoate from PNDs 14 to 28 or PNDs 42 to 56 negatively affected expression of IGF-I, IGF-II and IGF-1R in the endometrium (Hayashi et al. 2004). Collectively, these results support the 
hypothesis that IGFs of local and perhaps systemic origin regulate critical interactions between the stroma and epithelium that are crucial for development of the uterus and other female reproductive tract organs (Cunha \& Lung 1979, Cunha et al. 1989). Studies to determine the effects of modulating systemic and intrinsic IGF-I and IGF-II levels on postnatal ovine uterine development need to be conducted, but could be an effective tool for optimizing postnatal uterine development and perhaps adult uterine capacity and fertility in domestic ruminants as well as in humans (Carpenter et al. 2003b).

\section{Acknowledgements}

The authors thank Mr Kendrick LeBlanc for assistance with animal husbandry and surgery. This study was supported by NIH Grants HD38274 and P30 ES09106. Kanako Hayashi is a Lalor Foundation Fellow. The authors declare that there is no conflict of interest that would prejudice the impartiality of this scientific work.

\section{References}

Adesanya OO, Zhou J, Samathanam C, Powell-Braxton L \& Bondy CA 1999 Insulin-like growth factor 1 is required for G2 progression in the estradiol-induced mitotic cycle. PNAS 96 3287-3291.

Arai T, Busby W Jr \& Clemmons DR 1996 Binding of insulin-like growth factor (IGF) I or II to IGF-binding protein-2 enables it to bind to heparin and extracellular matrix. Endocrinology 137 4571-4575.

Baker J, Hardy MP, Zhou J, Bondy C, Lupu F, Bellve AR \& Efstratiadis A 1996 Effects of an Igf1 gene null mutation on mouse reproduction. Molecular Endocrinology 10 903-918.

Bartol FF, Wiley AA, Floyd JG, Ott TL, Bazer FW, Gray CA \& Spencer TE 1999 Uterine differentiation as a foundation for subsequent fertility. Journal of Reproduction and Fertility Supplement 54 287-302.

Baxter RC 2000 Insulin-like growth factor (IGF)-binding proteins: interactions with IGFs and intrinsic bioactivities. American Journal of Physiology. Endocrinology and Metabolism 278 E967-E976.

Bilby CR, Bader JF, Salfen BE, Youngquist RS, Murphy CN, Garverick HA, Crooker BA \& Lucy MC 1999 Plasma GH, IGF-I, and conception rate in cattle treated with low doses of recombinant bovine $\mathrm{GH}$. Theriogenology 51 1285-1296.

Carpenter KD, Gray CA, Bryan TM, Welsh TH Jr \& Spencer TE 2003a Estrogen and antiestrogen effects on neonatal ovine uterine development. Biology of Reproduction 69 708-717.

Carpenter KD, Gray CA, Noel S, Gertler A, Bazer FW \& Spencer TE $2003 b$ Prolactin regulation of neonatal ovine uterine gland morphogenesis. Endocrinology 144 110-120.

Carpenter KD, Hayashi K \& Spencer TE 2003c Ovarian regulation of endometrial gland morphogenesis and activin-follistatin system in the neonatal ovine uterus. Biology of Reproduction 69 851-860.

Clemmons DR 1997 Insulin-like growth factor binding proteins and their role in controlling IGF actions. Cytokine and Growth Factor Reviews 8 45-62.

Conover CA, Faessen GF, Ilg KE, Chandrasekher YA, Christiansen M, Overgaard MT, Oxvig C \& Giudice LC 2001 Pregnancy-associated plasma protein-a is the insulin-like growth factor binding protein-4 protease secreted by human ovarian granulosa cells and is a marker of dominant follicle selection and the corpus luteum. Endocrinology 142 2155-2158.
Cunha GR \& Lung B 1979 The importance of stroma in morphogenesis and functional activity of urogenital epithelium. In Vitro $\mathbf{1 5}$ $50-71$.

Cunha GR, Young P \& Brody JR 1989 Role of uterine epithelium in the development of myometrial smooth muscle cells. Biology of Reproduction 40 861-871.

DeChiara TM, Efstratiadis A \& Robertson EJ 1990 A growth-deficiency phenotype in heterozygous mice carrying an insulin-like growth factor II gene disrupted by targeting. Nature 345 78-80.

Delbe J, Blat C, Desauty G \& Harel L 1991 Presence of IDF45 (mIGFBP-3) binding sites on chick embryo fibroblasts. Biochemical and Biophysical Research Communications 179 495-501.

Echternkamp SE, Spicer LJ, Gregory KE, Canning SF \& Hammond JM 1990 Concentrations of insulin-like growth factor-I in blood and ovarian follicular fluid of cattle selected for twins. Biology of Reproduction 43 8-14.

Ferry RJ Jr, Katz LE, Grimberg A, Cohen P \& Weinzimer SA 1999 Cellular actions of insulin-like growth factor binding proteins. Hormone and Metabolic Research 31 192-202.

Firth SM \& Baxter RC 2002 Cellular actions of the insulin-like growth factor binding proteins. Endocrine Reviews 23 824-854.

Fowlkes JL 1997 Insulin-like growth factor-binding protein proteolysis: an emerging paradigm in insulin-like growth factor physiology. Trends in Endocrinology and Metabolism 8 299-306.

Gadd TS, Osgerby JC \& Wathes DC 2000 Regulation and localization of insulin-like growth factor binding protein-5 gene expression in the uterus and placenta of the cyclic and early pregnant ewe. Biology of Reproduction 62 1415-1421.

Gatford KL, Quinn KJ, Walton PE, Grant PA, Hosking BJ, Egan AR \& Owens PC 1997 Ontogenic and nutritional changes in circulating insulin-like growth factor (IGF)-I, IGF-II and IGF-binding proteins in growing ewe and ram lambs. Journal of Endocrinology 155 $47-54$.

Giudice LC, Conover CA, Bale L, Faessen GH, Ilg K, Sun I, Imani B, Suen LF, Irwin JC, Christiansen M, Overgaard MT \& Oxvig C 2002 Identification and regulation of the IGFBP-4 protease and its physiological inhibitor in human trophoblasts and endometrial stroma: evidence for paracrine regulation of IGF-II bioavailability in the placental bed during human implantation. Journal of Clinical Endocrinology and Metabolism 87 2359-2366.

Gray CA, Bartol FF, Tarleton BJ, Wiley AA, Johnson GA, Bazer FW \& Spencer TE 2001a Developmental biology of uterine glands. Biology of Reproduction 65 1311-1323.

Gray CA, Bazer FW \& Spencer TE $2001 b$ Effects of neonatal progestin exposure on female reproductive tract structure and function in the adult ewe. Biology of Reproduction 64 797-804.

Gray CA, Burghardt RC, Johnson GA, Bazer FW \& Spencer TE 2002 Evidence that absence of endometrial gland secretions in uterine gland knockout ewes compromises conceptus survival and elongation. Reproduction 124 289-300.

Greenwood PL, Hunt AS, Slepetis RM, Finnerty KD, Alston C, Beermann DH \& Bell AW 2002 Effects of birth weight and postnatal nutrition on neonatal sheep: III. Regulation of energy metabolism. Journal of Animal Science 80 2850-2861.

Gu Y, Branham WS, Sheehan DM, Webb PJ, Moland CL \& Streck RD 1999 Tissue-specific expression of messenger ribonucleic acids for insulin-like growth factors and insulin-like growth factor-binding proteins during perinatal development of the rat uterus. Biology of Reproduction $601172-1182$.

Hayashi K, Carpenter KD, Gray CA \& Spencer TE 2003 The activin-follistatin system in the neonatal ovine uterus. Biology of Reproduction 69 843-850.

Hayashi K, Carpenter K \& Spencer T 2004 Neonatal estrogen exposure disrupts uterine development in the postnatal sheep. Endocrinology 145 3247-3257.

Hwa V, Oh Y \& Rosenfeld RG 1999 The insulin-like growth factorbinding protein (IGFBP) superfamily. Endocrine Reviews 20 $761-787$. 
Johnson GA, Burghardt RC, Spencer TE, Newton GR, Ott TL \& Bazer FW 1999 Ovine osteopontin: Il. Osteopontin and alpha(v)beta(3) integrin expression in the uterus and conceptus during the periimplantation period. Biology of Reproduction 61 892-899.

Jones JI \& Clemmons DR 1995 Insulin-like growth factors and their binding proteins: biological actions. Endocrine Reviews 16 3-34.

Mazerbourg S, Callebaut I, Zapf J, Mohan S, Overgaard M \& Monget P 2004 Up date on IGFBP-4: regulation of IGFBP-4 levels and functions, in vitro and in vivo. Growth Hormone and IGF Research 14 71-84.

Mesiano S, Young IR, Baxter RC, Hintz RL, Browne CA \& Thorburn GD 1987 Effect of hypophysectomy with and without thyroxine replacement on growth and circulating concentrations of insulinlike growth factors I and II in the fetal lamb. Endocrinology 120 $1821-1830$.

Mesiano S, Young IR, Hey AW, Browne CA \& Thorburn GD 1989 Hypophysectomy of the fetal lamb leads to a fall in the plasma concentration of insulin-like growth factor I (IGF-I), but not IGF-II. Endocrinology 124 1485-1491.

Nayak NR \& Giudice LC 2003 Comparative biology of the IGF system in endometrium, decidua, and placenta, and clinical implications for foetal growth and implantation disorders. Placenta $24281-296$

Osgerby JC, Gadd TS \& Wathes DC 1999 Expression of insulin-like growth factor binding protein-1 (IGFBP-1) mRNA in the ovine uterus throughout the oestrous cycle and early pregnancy. Journal of Endocrinology 162 279-287.

Overgaard MT, Haaning J, Boldt HB, Olsen IM, Laursen LS, Christiansen M, Gleich GJ, Sottrup-Jensen L, Conover CA \& Oxvig C 2000 Expression of recombinant human pregnancy-associated plasma protein-A and identification of the proform of eosinophil major basic protein as its physiological inhibitor. Journal of Biological Chemistry 275 31128-31133.

Qin X, Byun D, Strong DD, Baylink DJ \& Mohan S 1999 Studies on the role of human insulin-like growth factor-II (IGF-II)-dependent IGF binding protein (hIGFBP)-4 protease in human osteoblasts using protease-resistant IGFBP-4 analogs. Journal of Bone and Mineral Research 14 2079-2088.

Rechler MM \& Brown AL 1992 Insulin-like growth factor binding proteins: gene structure and expression. Growth Regulation 2 55-68.

Reynolds TS, Stevenson KR \& Wathes DC 1997 Pregnancy-specific alterations in the expression of the insulin-like growth factor system during early placental development in the ewe. Endocrinology 138 886-897.

Sato T, Wang G, Hardy MP, Kurita T, Cunha GR \& Cooke PS 2002 Role of systemic and local IGF-I in the effects of estrogen on growth and epithelial proliferation of mouse uterus. Endocrinology $1432673-2679$.
Spencer TE, Stagg AG, Joyce MM, Jenster G, Wood CG, Bazer FW, Wiley AA \& Bartol FF 1999 Discovery and characterization of endometrial epithelial messenger ribonucleic acids using the ovine uterine gland knockout model. Endocrinology $\mathbf{1 4 0}$ 4070-4080.

Spicer LJ, Echternkamp SE, Wong EA, Hamilton DT \& Vernon RK 1995 Serum hormones, follicular fluid steroids, insulin-like growth factors and their binding proteins, and ovarian IGF mRNA in sheep with different ovulation rates. Journal of Animal Science 73 $1152-1163$.

Stevenson KR, Gilmour RS \& Wathes DC 1994 Localization of insulin-like growth factor-I (IGF-I) and -II messenger ribonucleic acid and type 1 IGF receptors in the ovine uterus during the estrous cycle and early pregnancy. Endocrinology 134 $1655-1664$

Taylor KM, Gray CA, Joyce MM, Stewart MD, Bazer FW \& Spencer TE 2000 Neonatal ovine uterine development involves alterations in expression of receptors for estrogen, progesterone, and prolactin. Biology of Reproduction 63 1192-1204.

Taylor KM, Chen C, Gray CA, Bazer FW \& Spencer TE 2001 Expression of messenger ribonucleic acids for fibroblast growth factors 7 and 10, hepatocyte growth factor, and insulin-like growth factors and their receptors in the neonatal ovine uterus. Biology of Reproduction 64 1236-1246.

Valentinis B, Bhala $A$, DeAngelis $T$, Baserga $\mathbf{R} \&$ Cohen $\mathbf{P}$ 1995 The human insulin-like growth factor (IGF) binding protein-3 inhibits the growth of fibroblasts with a targeted disruption of the IGF-I receptor gene. Molecular Endocrinology $9361-367$.

Wathes DC, Reynolds TS, Robinson RS \& Stevenson KR 1998aa Role of the insulin-like growth factor system in uterine function and placental development in ruminants. Journal of Dairy Science 81 1778-1789.

Wathes DC, Reynolds TS, Robinson RS \& Stevenson KR 1998bb Role of the insulin-like growth factor system in uterine function and placental development in ruminants. Journal of Dairy Science 81 1778-1789.

Yakar S, Liu JL, Stannard B, Butler A, Accili D, Sauer B \& LeRoith D 1999 Normal growth and development in the absence of hepatic insulin-like growth factor I. PNAS 96 7324-7329.

Received 1 June 2004

First decision 13 August 2004

Revised manuscript received 6 October 2004

Accepted 12 November 2004 